\title{
Effects of age, density and sex ratio on reproductive effort in male reindeer (Rangifer tarandus)
}

\author{
Atle Mysterud ${ }^{1 *}$, Øystein Holand ${ }^{2}$, Knut H. Røed ${ }^{3}$, Hallvard Gjøstein ${ }^{2}$, Jouko Kumpula ${ }^{4}$ and Mauri Nieminen ${ }^{4}$ \\ ${ }^{1}$ Department of Biology, Division of Zoology, University of Oslo, P.O. Box 1050 Blindern, N-0316 Oslo, Norway \\ 2 Department of Animal Science, Agricultural University of Norway, P.O. Box 5025, N-1432 Ås, Norway \\ ${ }^{3}$ Department of Morphology, Genetics and Aquatic Biology, The Norwegian School of Veterinary Science, P.O. Box 8146, \\ Department N-0033 Oslo, Norway \\ ${ }^{4}$ Finnish Game and Fisheries Research Institute, Reindeer Research Station, Fin-99910 Kaamanen, Finland \\ (Accepted 8 April 2003)
}

\begin{abstract}
In sexually dimorphic ungulates, male reproductive success depends on fighting with other males for access to females during a brief rutting season. Large body size is necessary for success in intrasexual competition, and a few large-sized males are often able to monopolize access to female groups. Earlier studies have reported that reproductive effort increases with age until prime-age is reached, and one study that population density lowered effort in (older) males. No study has directly assessed whether there is within-age-class variation in effort resulting from varying levels of intra-male competition. It is reported here the weight loss during the rutting season of 54 individual male reindeer Rangifer tarandus coming from eight herds with varying density $\left(3.3-6.0 \mathrm{deer} / \mathrm{km}^{2}\right)$ and sex ratio (4-28\% males). In agreement with earlier studies, reproductive effort was lower for young (1- to 2-year-old) than for prime-aged (3- to 5-year-old) males both on an absolute and relative scale. Among 1-year-old males $(n=33)$, effort was lower as sex ratio became closer to even, but density during the rutting season had no effect. This suggests that yearling males take a more active role when prime-aged males are absent. In addition to the insight into male ungulate life history, understanding male rutting behaviour may also have implications for population dynamics.
\end{abstract}

Key words: age, body weight, cervids, rutting, life history, Rangifer tarandus

\section{INTRODUCTION}

Reproductive success in male ungulates depends on fighting with other males for access to females during a brief rutting season (Clutton-Brock, Guinness \& Albon, 1982). Large body size is necessary for success in intrasexual competition, and a few large-sized males are often able to monopolize access to female groups. As it may take years to reach the large body size necessary to monopolize harems (Mysterud et al., 2001), reproductive success is therefore typically highly asymmetric between males of different ages (Clutton-Brock et al., 1982; Clutton-Brock, Albon \& Guinness, 1988; Pemberton et al., 1992; Asa, 1999; Coltman et al., 1999; Røed et al., 2002). Investing heavily in rutting at the onset of winter may result in reduced likelihood of survival. Indeed, prime-aged males have higher winter mortality than young individuals (Festa-Bianchet, 1989; Ditchkoff et al., 2001), which is in contrast to patterns

*All correspondence to: A. Mysterud.

E-mail: atle.mysterud@bio.uio.no reported for females (Gaillard et al., 2000). This probably reflects their differential investment. Prime-aged males use more time on rutting activities and less time on foraging than younger males during the rutting season (Maher \& Byers, 1987; Miquelle, 1990). Yearling males typically adopt a less strenuous 'sneaker' strategy when older males are present, resulting in a much lower reproductive effort than prime-aged males (Yoccoz et al., 2002).

Young males are fully capable of inseminating females, given the opportunity, and they sire some offspring. For example, although a few large-horned, mature (age $8+$ years) bighorn sheep Ovis canadensis rams had high reproductive success, younger rams sired c. $50 \%$ of the lambs in a population subject to trophy harvesting (Coltman et al., 2002). Most large herbivore populations in Europe and North America are heavily harvested. Harvests are often sex- and/or age-biased and may have a considerable impact both on the population dynamics (Solberg et al., 1999) as well as on the remaining age and sex structure of the population (Langvatn \& Loison, 1999). Despite this, there is little information about how this may affect the reproductive 
effort of yearling males. For moose Alces alces, it was suggested that decreased weight of yearling males over time was the result of their rutting behaviour when the sex ratio of the population became increasingly femalebiased (Solberg \& Sæther, 1994). Indeed, data on reproductive effort in males are scarce in general. For seven male reindeer Rangifer tarandus aged 1-7 years, weight loss during rutting increased with age (Kojola, 1985). Similarly, in red deer Cervus elaphus, rutting effort peaked for prime-age males, and the youngest age-classes typically lost no weight (Yoccoz et al., 2002). Male red deer had a lower effort with increasing population density, probably due to decreased condition when entering rut at high density (Yoccoz et al., 2002).

In this study, the first manipulations of level of mating competition in male ungulates are provided and data presented from 54 reindeer males weighed before and after the rutting season. Tests were undertaken on whether reproductive effort increases with age (Kojola, 1985; Yoccoz et al., 2002), and on whether effort in yearling males depends on density and levels of competition for access to females (Solberg et al., 1994). In addition to the insight into male life history, understanding male rutting behaviour may also have implications for population dynamics (Mysterud, Coulson \& Stenseth, 2002), because it affects subsequent survival of males (Ditchkoff et al., 2001) and also timing of calving (Holand et al., 2003).

\section{MATERIALS AND METHODS}

\section{Study area and experimental animals}

The study was conducted at the Kutharju Field Reindeer Research Station, in Kaamanen, Finland $\left(69^{\circ} \mathrm{N}, 27^{\circ} \mathrm{E}\right)$ (Holand et al., 2003). The total area of $43 \mathrm{~km}^{2}$ is fenced and sub-divided into several smaller enclosures. This study was conducted in the north-west (Lauluvaara, $13.8 \mathrm{~km}^{2}$, in 1996-1997) and south-east section (Sinioivi, $15 \mathrm{~km}^{2}$, in 1996-2001). Birch Betula spp. and pine Pinus sylvéstris forests with numerous lakes and bogs dominate the habitat in these areas. The habitat composition is similar in the 2 enclosures. The experimental herd is supplementary fed during winter only (Holand et al., 2003).

\section{Manipulated herds}

During the rutting periods from 1996 through 2001, the composition of the male segment of herds was manipulated, while the female segment was kept similar between treatments (Holand et al., 2003). These are data from the same manipulations as we have reported on reindeer calving from years 1996-97 (Holand et al., 2003). Males were weighed (to nearest $\mathrm{kg}$ ) both before (second half of September) and after (first half of November) the rutting season. Weight loss of 1-year-olds $(n=330)$, 2-year-olds $(n=6)$, 4-year-olds $(n=6)$ and 5-year-olds $(n=3)$ were sampled. These derive from a total of 8 herd compositions with variable sex ratio and density (Table 1). The proportion of males present was manipulated from $4 \%$ to $28 \%$, and the density during rutting season from 3.3 to 6.0 reindeer per $\mathrm{km}^{2}$ (Table 1 ). Density and sex ratio were not correlated $(n=8, r=-0.243, P=0.562)$.

\section{Statistical analyses}

Linear models and linear mixed models were used to assess the relationship between weight change during rut and age, sex ratio (proportion of males) and density. To avoid pseudoreplication, a linear mixed model (with male identity as a random factor) was used in the analysis of all males, because a few males were used more than once (e.g. included when both 1 and 2 years of age). Primeaged males were only present in a few herds (Table 1). Therefore a separate model including only yearling males was run when testing for the possible effects of density and sex ratio. Results are given as parameter-estimates (least-square) with $95 \%$ confidence intervals. As graphical evidence suggested an abrupt shift in effort with age (Fig. 1), ages were categorized into 2 classes: young (1-2 years of age) and adult (3-5 years of age). A logarithmic transformation $[\ln ($ weight)] of body weight was used to achieve residuals with constant variance. This transformation also enabled relative weight loss (Yoccoz et al., 2002) to be studied, which is important because larger males probably lose more weight on an absolute scale. All analyses were done in SPlus (Venables \& Ripley, 1994).

\section{RESULTS}

Relative and absolute weight loss of males during the rutting season was higher for prime-aged (3-5 years) than for younger (1-2 years) males (Fig. 1; mean difference between age categories of $-0.159,95 \% \mathrm{CI},-0.198$, $-0.121)$. Figure 1 gives evidence for this rather abrupt shift in effort with age between 2- and 3-year-olds. Considering only 1-year-old males, effort was markedly lower the more males that were present (Fig. 2; mean $=$ $-0.617,95 \% \mathrm{CI},-0.879$ to -0.356$)$. Note, however, that this result was dependent on inclusion of data from one herd with a more even sex ratio than the other herds (Sinioivi, 1997, Table 1). There was no evidence that population density affected reproductive effort of yearling males (mean $=0.008,95 \% \mathrm{CI},-0.011$ to 0.027 ).

\section{DISCUSSION}

Life history in male ungulates differs markedly from that of females, but has received much less attention (Yoccoz et al., 2002). Probably owing to logistic difficulties, little information on reproductive effort in males is obtained 
Table 1. An overview of the eight herd compositions used in the study. Note that herds were only separated during the brief rutting period

\begin{tabular}{|c|c|c|c|c|c|c|c|c|c|}
\hline \multirow[b]{2}{*}{ Area - year } & \multirow[b]{2}{*}{ Females $(n)$} & \multirow[b]{2}{*}{ Males $(n)$} & \multicolumn{5}{|c|}{ Males by age class $(n)$} & \multirow{2}{*}{$\begin{array}{l}\text { Sex ratio } \\
(\% \text { males })\end{array}$} & \multirow{2}{*}{$\begin{array}{l}\text { Density } \\
\left(n / \mathrm{km}^{2}\right)\end{array}$} \\
\hline & & & 1 & 2 & 3 & 4 & 5 & & \\
\hline Lauluvaara - 1996 & 46 & 6 & 6 & 0 & 0 & 0 & 0 & 11.5 & 3.8 \\
\hline Lauluvaara - 1997 & 47 & 4 & 4 & 0 & 0 & 0 & 0 & 7.8 & 3.7 \\
\hline Sinioivi - 1996 & 43 & 6 & 3 & 0 & 0 & 3 & 0 & 12.2 & 3.3 \\
\hline Sinioivi - 1997 & 47 & 18 & 9 & 6 & 0 & 0 & 3 & 27.7 & 4.3 \\
\hline Sinioivi - 1998 & 81 & 6 & 0 & 0 & 6 & 0 & 0 & 6.9 & 5.8 \\
\hline Sinioivi - 1999 & 71 & 3 & 0 & 0 & 0 & 3 & 0 & 4.1 & 4.9 \\
\hline Sinioivi - 2000 & 74 & 3 & 3 & 0 & 0 & 0 & 0 & 3.9 & 5.1 \\
\hline Sinioivi - 2001 & 79 & 11 & 11 & 0 & 0 & 0 & 0 & 12.2 & 6.0 \\
\hline
\end{tabular}

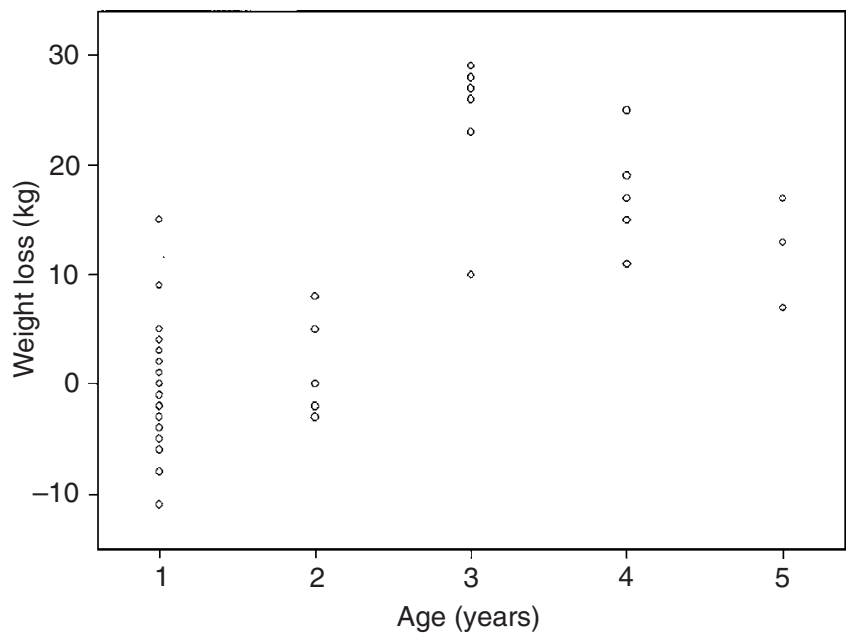

Fig. 1. Rutting weight loss in male reindeer Rangifer tarandus of different age classes.

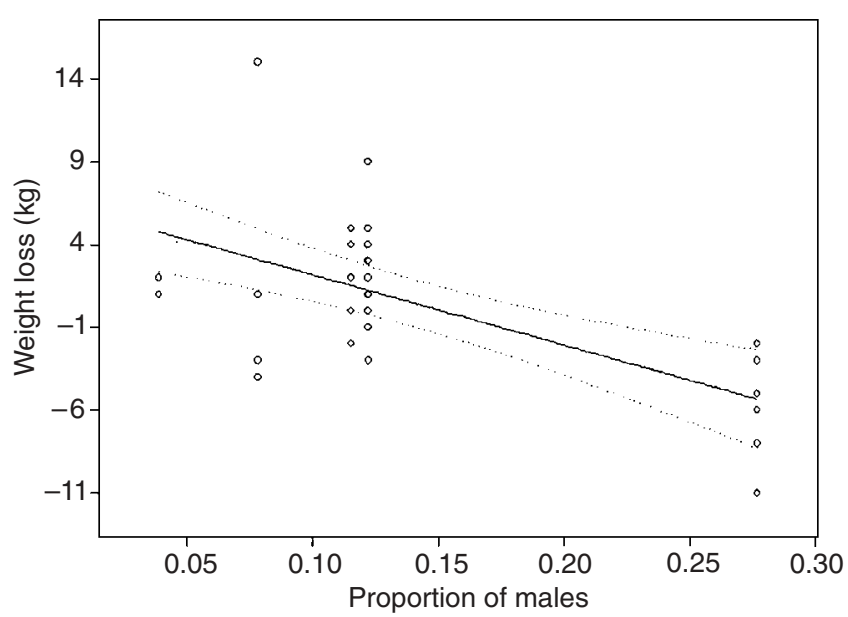

Fig. 2. Rutting weight loss in yearling male reindeer Rangifer tarandus as a function of population sex ratio. Dotted lines indicate $95 \%$ confidence intervals.

from direct measures of weight loss. A few reports on weight loss estimated from animals shot at different stages of the rut are available (Bobek, Perzanowski \& Weiner,
1990; Dzieciolowski, Babinska-Werka, Wasilewski et al., 1996; Milner, Alexander \& Griffin, 2002; Yoccoz et al., 2002). Only one earlier study had access to longitudinal data, but was on only seven semi-domestic reindeer (Kojola, 1985). We here show that prime-aged male reindeer lose more weight during rutting than younger males, which is consistent with earlier studies on reindeer (Kojola, 1985) and red deer (Dzieciolowski et al., 1996; Yoccoz et al., 2002). Rather than a gradual increase in effort with age, effort was low for 1- and 2-year-olds, while increasing sharply for 3- to 5-year-olds (Fig. 1). Such an abrupt change in effort is also suggested in bighorn sheep, as mortality increased when males enter more actively in rutting activity at the age of 6 years (Jorgenson et al., 1997).

Variation in reproductive effort within male age classes based on manipulations has not been reported earlier, and was made possible by the use of semi-domestic reindeer herds. Our analysis suggests that reproductive effort in yearling males depends on the sex ratio of the population. This result was mainly caused by the decrease in weight of yearling males when the numbers of males in the herd increased to $28 \%$ (including a high proportion of prime-aged males; Fig. 2, Table 1), indicating that they took little part in rutting activities when intrasexual competition is likely to be fierce. This correlates well with the study of temporal changes in weight of yearling male moose during a period in which both density increased and sex ratio became increasingly female-biased (Solberg et al., 1994). Yearling male weight, but not female weight, was more closely (negatively) correlated with sex ratio than density, suggesting that decline in weight of yearling males was the result of increased rutting behaviour when few older males were present (Solberg et al., 1994). However, studies on dall sheep Ovis dalli and bighorn sheep found decreased effort for adults with increasingly female-biased sex ratios (Singer \& Zeigenfuss, 2002).

Effort of yearling males did not vary according to population density during the rutting season in our study. In red deer, effort by older males was lower with increasing density (Yoccoz et al., 2002). However, our results are not necessarily in contrast to this. In our study, condition was similar before the rutting season, as density was similar 
in all years except during the rutting season when herds were manipulated (Holand et al., 2003). The reason for the density-dependent effect in red deer males was suggested to be because they entered the rut in poor condition at high population density (Yoccoz et al., 2002).

The variable effort in yearling males depending on population sex ratio reported here, suggests that survival of yearling males may also vary as a function of sex ratio and hence affect population dynamics.

\section{Acknowledgements}

We thank V. Tervonen and his crew at Kutuharju Experimental Reindeer Research Station for valuable assistance and logistic support and $\mathrm{H}$. Tørmänen for keeping records of the data. The Research Council of Norway and the Norwegian Reindeer Husbandry Research Council supported this research.

\section{REFERENCES}

Asa, C. S. (1999). Male reproductive success in free-ranging feral horses. Behav. Ecol. Sociobiol. 47: 89-93.

Bobek, B., Perzanowski, K. \& Weiner, J. (1990). Energy expenditure for reproduction in male red deer. J. Mammal. 71: 230-232.

Clutton-Brock, T. H., Albon, S. D. \& Guinness, F. E. (1988). Reproductive success in male and female red deer. In Reproductive success: 325-343. Clutton-Brock, T. H. (Ed.). Chicago: University of Chicago Press.

Clutton-Brock, T. H., Guinness, F. E. \& Albon, S. D. (1982). Red deer. Behaviour and ecology of two sexes. Edinburgh: Edinburgh University Press.

Coltman, D. W., Festa-Bianchet, M., Jorgenson, J. T. \& Strobeck, C. (2002). Age-dependent sexual selection in bighorn rams. Proc. R. Soc. Lond. Ser. B Biol. Sci. 269: 165-172.

Coltman, D. W., Smith, J. A., Bancroft, D. R., Pilkington, J., MacColl, A. D. C., Clutton-Brock, T. H. \& Pemberton, J. M. (1999). Density-dependent variation in lifetime breeding success and natural and sexual selection in Soay rams. Am. Nat. 154: 730-746.

Ditchkoff, S. S., Welch, E. R., Lochmiller, R. L., Masters, R. E. \& Starry, W. R. (2001). Age-specific causes of mortality among male white-tailed deer support mate-competition theory. J. Wildl. Manage. 65: 552-559.

Dzieciolowski, R., Babinska-Werka, J., Wasilewski, M. \& Goszczynski, J. (1996). Physical condition of red deer in a high density population. Acta Theriol. 41: 93-105.
Festa-Bianchet, M. (1989). Survival of male bighorn sheep in southwestern Alberta. J. Wildl. Manage. 53: 259-263.

Gaillard, J.-M., Festa-Bianchet, M., Yoccoz, N. G., Loison, A. \& Toigo, C. (2000). Temporal variation in fitness components and population dynamics of large herbivores. Annu. Rev. Ecol. Syst. 31: 367-393

Holand, Ø., Røed, K. H., Mysterud, A., Kumpula, J. M., Nieminen, M. \& Smith, M. E. (2003). The effect of sex ratio and male age structure on reindeer calving. J. Wildl. Manage. 67: 25-33.

Jorgenson, J. T., Festa-Bianchet, M., Gaillard, J.-M. \& Wishart, W. D. (1997). Effects of age, sex, disease, and density on survival of bighorn sheep. Ecology 78: 1019-1032.

Kojola, I. (1985). Influence of age on the reproductive effort of male reindeer. J. Mammal. 72: 208-210.

Langvatn, R. \& Loison, A. (1999). Consequences of harvesting on age structure, sex ratio and population dynamics of red deer Cervus elaphus in central Norway. Wildl. Biol. 5: 213-223.

Maher, C. R. \& Byers, J. A. (1987). Age-related changes in reproductive effort of male bison. Behav. Ecol. Sociobiol. 21: 91-96.

Milner, J. M., Alexander, J. \& Griffin, C. (2002). A highland deer herd and its habitat. Letterewe Estate: Red Lion House.

Miquelle, D. G. (1990). Why don't bull moose eat during the rut? Behav. Ecol. Sociobiol. 27: 145-151.

Mysterud, A., Coulson, T. \& Stenseth, N. C. (2002). The role of males in the population dynamics of ungulates. J. Anim. Ecol. 71: 907-915.

Mysterud, A., Yoccoz, N. G., Stenseth, N. C. \& Langvatn, R. (2001). The effects of age, sex and density on body weight of Norwegian red deer: evidence of density-dependent senescence. Proc. $R$. Soc. Lond. Ser. B Biol. Sci. 268: 911-919.

Pemberton, J. M., Albon, S., Guinness, F. E., Clutton-Brock, T. H. \& Dover, G. A. (1992). Behavioral estimates of male mating success tested by DNA fingerprinting in a polygynous mammal. Behav. Ecol. 3: 66-75.

Røed, K. H., Holand, Ø., Smith, M. E., Gjøstein, H., Kumpula, J. \& Nieminen, M. (2002). Reproductive success in reindeer males in a herd with varying sex ratio. Mol. Ecol. 11: 1239-1243.

Singer, F. J. \& Zeigenfuss, L. C. (2002). Influence of trophy hunting and horn size on mating behavior and survivorship of mountain sheep. J. Mammal. 83: 682-698.

Solberg, E. J. \& Sæther, B.-E. (1994). Male traits as life-history variables: annual variation in body mass and antler size in moose (Alces alces). J. Mammal. 75: 1069-1079.

Solberg, E. J., Sæther, B.-E., Strand, O. \& Loison, A. (1999). Dynamics of a harvested moose population in a variable environment. J. Anim. Ecol. 68: 186-204.

Venables, W. N. \& Ripley, B. D. (1994). Modern applied statistics with S-plus. New York: Springer Verlag.

Yoccoz, N. G., Mysterud, A., Langvatn, R. \& Stenseth, N. C. (2002). Age- and density-dependent reproductive effort in male red deer. Proc. R. Soc. Lond. Ser. B Biol. Sci. 269: 1523-1529. 